\title{
The Duelling NarRatives Of Religious Freedom: A COMMENT ON SYNDICAT NORTHCREST V. AMSELEM
}

\author{
KATHRYN BROMLEY ChAN"
}

\section{INTRODUCTION}

So on the first day of the seventh month Ezra the priest brought the Law hefore the assembly, which was made up of men and women and all who were able 10 understand. He read it aloud from daybreak till noon..

On the second day of the month, the heads of all the families, along with the priests and the Levites, gathered around Ezra the scribe to give altention to the words of the Law. They found written in the Law, which the Lord had commanded through Moses, that the Israelites were to live in booths during the feast of the seventh month and that they should proclaim this word and spread it throughout their towns and in Jerusalem: "Go out into the hill country and bring back branches from olive and wild olive irees, and from myrtes, palms, and shade trees, to make booths" - as it is written: Nehemiah 8:2-3. 13-15.

As it is written. It is an affirmation of obedience, the idiom of a people that understands what it means to spend a lifetime studying and following the Law. It expresses a willingness to abide by a set of externally imposed rules, a readiness to accept God's divine, if sometimes inexplicable, will. And it may have drifted through the mind of Moïse Amselem in September 1996, as he set about constructing a temporary booth, or "succah," on the balcony of his new luxury apartment in Montreal, in preparation for the Jewish religious festival of Succot. As it is written.

Mr. Amselem's fight to erect a temporary dwelling on his balcony for the nine days of Succot,' despite apartment bylaws prohibiting the erection of "constructions of any kind" on individual balconies, gave rise to a lengthy court battle between the syndicate of coownership of Le Sanctuaire du Mont-Royal, and several of its Orthodox Jewish residents. Ultimately, it resulted in a split judgment by the Supreme Court of Canada, which contains a number of significant pronouncements on the scope of protected religious practices in Canada, the role of the courts in adjudicating religious claims, and the nature of religious freedom and religion itself. ${ }^{2}$ Syndicat Northcrest v. Amselem is an important decision for religious freedom in Canada, one which carves out a significant space in our society for individuals to manifest religious beliefs and safeguards those beliefs from the interference of the state. It is also a decision that demonstrates the unifying power of the Quebec and Canadian Charters, and the ability of our rights discourse to recognize and accommodate a wide range of claims.

LL.M. candidate. MCGill Faculty of Law, and member of the Law Socicty of British Columbia. The author would like to thank Professor Shauna Van Praagh. Professor Karla O'Regan and Blake Bromley for their helpful comments on earlier drafts.

- Suecot is a nine-day religious festival that "commemorales the 40-year period during which, according to Jewish tradition, the Children of Israel wandered in the desert, living in temporary shellers": Syndicat Northcrest v. Amselem, [2004] 2 S.C.R. 551, 2004 SCC 47 at para. 5 [Amselem]. 
At the same time, however, Syndicat Northorest $v$. Amselem highlights the fact that our most fundamental legal principles may hold very different meanings for different individuals and groups. The Supreme Court of Canada adopted a very individualistic vision of religion in the Amselem decision, and told a story of religious freedom that emphasizes subjectivity, self-definition and personal choice. However, there are many other stories or "narratives" of religious freedom that might be recounted by religious communities in Canada, narratives which emphasize the value of obedience, personal commitment and community belief. This comment explores the tension created by the existence of these duelling narratives, and the threat they may pose to notions of the "unifying" rights discourse of the courts. It examines how these narratives may impact religious communities' commitments to the Supreme Court's interpretation of religious freedom, and explores the possibility that Syndicat Northcrest $v$. Amselem may actually alienate the Court further from the religious communities it seeks to control and protect. As such, the comment argues, the decision affords a good opportunity to reconsider the role of the courts in constitutional adjudication, and to consider how they might prevent the narratives that "state" and "subject" attach to our constitutional guarantees from getting too far apart.

\section{Facts ANd JUdictal History}

In 1996, not long after Mr. Amselem finished building his dwelling for the festival of Succot, the syndicate of Le Sanctuaire advised him that the succah violated the declaration of co-ownership he had signed upon purchasing his apartment, and asked him to remove it. As the syndicate pointed out, the bylaws set out in the declaration prohibited owners from erecting "constructions of any kind" on balconies, or from altering "exterior elements contributing to the overall harmony of the building's appearance" without the written permission of the syndicate's Board of Directors. ${ }^{3}$ Accordingly, as Succot approached in 1997, Mr. Amselem wrote a letter to the syndicate, seeking permission to erect a succah on his balcony. The syndicate refused, proposing instead that Mr. Amselem and the other Orthodox Jewish residents of Le Sanctuaire be allowed to set up a communal succah in the residential gardens. The residents refused this offer, stating that they required "their own succah, each on his own balcony"- to fulfill their personal religious beliefs. When the syndicate again refused permission, the residents nonetheless set about constructing individual succahs on each of their balconies. The syndicate responded by applying to the Quebec Superior Court for a permanent injunction "prohibiting the appellants from setting up succahs and, if necessary. permitting their demolition.""

The Quebec Superior Court granted the syndicate's injunction application.' Rochon J. found that Le Sanctuaire's bylaws clearly prohibited the erection of succahs on balconies, and that these restrictions were consistent with the Quebec Civil Code's provisions on the rights of co-owners. With regard to the Orthodox Jewish residents' claim that the bylaws 
infringed their freedom of religion guaranteed by s. 3 of the Quebec Charter.' Rochon J. held that such a claim could only be maintained if the particular religious practice being relied upon was "considered mandatory pursuant to the religious teaching upon which the right is based." Favouring the evidence of the syndicate's witness. Rabbi Levy, over that of the rabbi called by the Orthodox Jewish residents, Rochon J. concluded that practicing Jews were under no obligation to erect their own succahs, or to place them in particular locations. As such, the bylaws did not violate the religious freedom of the Orthodox Jewish residents, nor discriminate against them on the basis of religion.

The Court of Appeal agreed with Rochon J.'s decision to issue a permanent injunction, albeit on somewhat different grounds." Writing for the majority, Dalphond J.A. held that the Orthodox Jewish residents had waived their freedom of religion by signing the declaration of co-ownership. While it remained open to the residents to argue that the bylaws were discriminatory, Dalphond J.A. found that the bylaws were neutral in their application, and that the residents' religious discrimination claim could not be sustained because they had not proved they were religiously obligated to construct succalss on their own balconies. ${ }^{10}$ Justice Morin disagreed with this restricted view of freedom of religion in his concurring opinion, stating that only sincerity of belief must be proved to invoke a religious freedom claim." Accordingly, he found that the bylaws had violated the freedom of religion of the Orthodox Jewish residents and discriminated against them on religious grounds. Ultimately, however, Morin J.A. concluded that the syndicate had discharged its obligation to reasonably accommodate the residents' religious beliefs pursuant to the justification test for discriminatory acts set out by the Supreme Court of Canada in the Meiorin decision. ${ }^{12}$ As such, he agreed with the majority's decision to dismiss the appeal.

\section{Decision of the SUPREME COLIRT OF CANAlBa}

The Supreme Court of Canada split five to four in favour of the Orthodox Jewish residents, with the majority holding that freedom of religion protected the residents' decision to erect succahs on their own balconies, and that the bylaws infringed this freedom in a manner that could not be justified by the "minimal" intrusions on the co-owners' property and security rights. The dissent and majority judgments diverge most significantly in their view of the scope of religious practices protected by Charter guarantees of religious freedom. and the courts' role in identifying such practices. Three of the four dissenting judges concluded that litigants must prove that their beliefs and practices are "objectively connected to a religious precept that follows from a text or another article of faith"13 in order to claim

, Charter of Human Rights and Freedoms, R.S.Q. C. C-12, s. 3 ("every persen is the possessor of the fundamental freedoms, including freedom of conscience. freedoun of religion. freedom of opinion. freedom of expression, freedom of peaceful assembly and freedom of associalion") [Quebec (harter]. Amselem (C.S.). supra note 6 at 1907 [translaled by author].

Syndicat Northcrest c. Amselem, [2002] J.Q 705 (C.A.)

Ibid. at paras. 150-54.

lbid. at para. 32

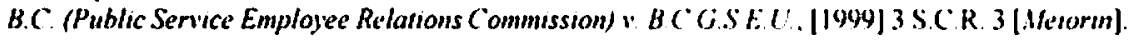
Amselem. supra note 1 at para. 141. Bastarache J. Juslice Binnic wrole a separale dissenting opuion. holding that the residents" claim fell "within the prolected zonc of religious freedom" at para. 189. hut that greater weight must be given to the private contract which they had voluntarily signed. at paras. 207-209. 
religious freedom protections. However, the majority of the Supreme Court was adamant that "courts are not arbiters of scriptural interpretation"14 and do not have the authority to question the validity of any person's religious belief. According to the majority judgment, a court's role in assessing religious claims is limited to a "minimal inquiry into sincerity,"15 which is "intended only to ensure that a presently asserted religious belief is in good faith, neither fictitious nor capricious, and that it is not an artifice."

Two other aspects of Syndicat Northcrest v. Amselem represent particularly significant developments in Canada's freedom of religion jurisprudence. First, the majority judgment sets out, for the first time, an "outer definition" of the "religion" that is protected by Canadian law:

Defined broadly, religion typically involves a particular and comprehensive system of faith and worship. Religion also tends to involve the belief in a divine, superhuman or controlling power. In essence, religion is about freely and deeply held personal convictions or beliefs connected to an individual's spiritual faith and integrally linked to one's self-definition and spiritual fulfilment, the practices of which allow individuals to foster a connection with the divine or with the subject or object of that spiritual faith. ${ }^{17}$

Second, the judgment endorses a "subjective, personal and deferential definition of freedom of religion," ${ }^{18}$ which stresses the right of every individual to manifest whatever beliefs he chooses in whatever way he likes:

[F]reedom of religion consists of the freedom to undertake practices and harbour beliefs, having a nexus with religion, in which an individual demonstrates he or she sincerely believes or is sincerely undertaking in order to connect with the divine or as a function of his or her spiritual faith. irrespective of whether a particular practice or belief is required by official religious dogma or is in conformity with the position of religious officials. $^{19}$

Under this definition, a religious freedom claimant need not show that his or her religious beliefs represent obligatory tenets of a particular faith, nor even that they are "recognized as valid by other members of the same religion." ${ }^{20}$ Because religious belief is of a "fluid" and "vacillating" nature, the fact that a claimant espoused different religious practices and beliefs in the past also will not prejudice his or her claim. ${ }^{21}$ Once an individual has shown a nontrivial interference with his or her religious freedom, however, the court will still "consider how the exercise of their right impacts upon the rights of others in the context of the competing rights of private individuals. Conduct which would potentially cause harm to or interference with the rights of others [will] not automatically be protected." ${ }^{.22}$

Thomas v. Review Board of the Indiana Employment Security Division, 450 U.S. 707 at $715-16$ (1981), cited in ibid. at para 45.

Laurence H. Tribe, American Constimfional Lanv, 2d ed. (Mincola, N.Y.: Foundation Press, 1988) al 1245-46, cited in Amselem, sipra nole I at para. 52.

Amselem, ibid. at parn. 52.

lbid. at para. 39.

Ibid. at para. 45.

Jbid. at para. 46.

Jbid. at para. 43.

ibid. at para. 53.

Ibid. at para. 62. 


\section{THE UNIFYING NATURE OF RIGHTS DISCOURSE.}

The Supreme Court of Canada's decision in Amselem is, on many levels, a testimony to the "unity and the order secured by the system of rights,"23 and to the ability of our courts to accommodate the distinctive identities of religious groups within the structures of Canada's "essentially secular" society. ${ }^{24}$ The Amselem litigation began, in the words of Martha Minow, as a struggle between the "one" and the "many," as a challenge posed to the contractabiding polity by a small, religious group called to follow a higher law. By pulling out their wood and hammers, in open defiance of the rules and protestations of the syndicate, Molse Amselem and the other Orthodox Jewish residents conveyed a strong message of separateness to the other residents of Le Sanctuaire and the polity at large: "We care little about contractual promises or the aesthetic sensibilities of our neighbors," the "one" heard; "we follow another set of rules, applicable to us alone."

However, the message of separateness that was communicated by Molse Amselem's construction efforts in 1996 was quickly transformed into a plea for likeness, as the Orthodox Jewish residents sought to respond to the injunction application in a manner recognized by Quebec law. Suddenly, the "one" heard a new message: "[T]his constitutional democracy has promised us, as you, the right to hold and manifest whatever beliefs or opinions our conscience dictates." This radical reformulation of the residents' message provides a good illustration of how rights claims by minority groups may be seen to promote unity in pluralist societies. As Minow explains:

[R]ights claims deployed to ensure respect for ethnic, racial, or cultural differences (couched in individual or group terms) do not jeopardize unity because they channel dissent and opposition into a communal language and secure participation and respect for the dominant structures of law. The willingness of a minority group to use the language of rights thus constitutes in a profound sense a willingness to join the dominant community. Linguistically, conceptually, and politically, rights claims draw the claimants into the community that prescribes the terms for claiming and obtaining rights. Framing their assertions in rights terms, the claimants at least gesture toward obedience to the dominant legal system and the state that maintains it. ${ }^{26}$

In this way, Minow claims, rights claims evoke an image of "Russian nesting dolls in which each subcommunity fits comfortably within the larger enclosure of the dominant state."27

On one level, Syndical Northcrest $v$. Amselem fits quite comfortably into this "Russian nesting dolls" model, which highlights the peace and order that may emerge from a unifying rights discourse. By pursuing their struggle to preserve their religious practices in a judicial forum, the Orthodox Jewish residents made a significant "gesture towards obedience" of the Politics, and Rights (Ann Arbor: University of Michigan Press. 1995) 347 at 357 lain T. Benson, "Considering Secularism" in Douglas Farrow, ed., Recognizing Religion in a Secular Sociely: Essays in Pluralism. Religion and Public Policy' (Montreal \& Kingston: McGill-Qucen's University Press, 2004) 83. 
Canadian legal system. During the course of the litigation, the voice of the Orthodox Jews was united with that of Presbyterians and Sikhs, as an assortment of religious groups joined together in the common goal of maximizing the space carved out for religious communities within the state. ${ }^{28}$ Most significantly, perhaps, the Orthodox Jewish residents' claim to separateness was re-articulated in a way that was compatible with the "communal language" of Canadian constitutional law, and that recognized the authority of the Quebec Charter and the legitimacy of the syndicate's claim. In this way, the Amselem decision seems to achieve what Minow calls an image of Russian nesting dolls, and the Chief Justice of Canada calls the law's "seemingly paradoxical task of asserting its own ultimate authority while carving out a space within itself in which individual and communities can manifest alternate, and often competing sets of ultimate commitments."29

However, the Court's accommodation of the Orthodox Jewish residents' competing, ultimate commitments did not come without a cost. As Minow points out, rights claims place sub-communities "under the authority of the larger society," which a court dictates the scope and source of their autonomy and "prescribes the terms for claiming and obtaining rights." ${ }^{11}$ The Supreme Court made full use of this power in Syndicat Northcrest $v$. Amselem, dictating a number of terms which will now govern the obtaining and exercise of religious freedom for Orthodox Jews and other religious communities in Canada.

What then, were the terms prescribed by the Supreme Court? First, the Amselem decision confirms that religious minority rights must coexist with other "correspondingly important rights"32 and societal values that are recognized in a democratic society. These include not only other "fundamental freedoms" such as expression and association, but aesthetic, economic and security interests in personal property. While it may still be simpler to establish a "substantial" violation of a religious right than a property right, Syndicat Northcrest $v$. Amselem strongly suggests that freedom of religion enjoys no higher protection per se than the other rights set out in the Quebec and Canadian Charters. Second, the Amselem decision requires that religious groups give up any claim that certain religious practices are entitled to special protection because of their fundamental or mandatory nature, or because of the particular significance that they hold for the community. In fact, the language of the majority could be taken to suggest that practices undertaken because they are "required" or "conformist" are further from the core of what freedom of religion protects. ${ }^{33}$

2k The Evangelical Fellowship of Canada, the Seventh-day Adventist Church in Canada, and the World Sikh Organization all intervened on behalf of Molse Amselem and the Orthodox Jewish residents: see Amselem, supra note 1. The Right Honourable Beverley McLachlin, "Freedom of Religion and the Rule of Law: A Canadian Perspective" in Farrow, supra note 24, 12 at 16.

Minow, supra note 23 at 361.

Jbid. at 355.

Amselem, supra note I at para. I.

After aifirming that freedom of religion protects sincerely held beliefs that are not in conformity with the position of religious officials, the majority continued (ibid. at para. 47):

But, at the same time, this freedom encompasses objective as well as personal notions of religious belief. "obligation," precept, "commandment," custom or ritual. Consequently, both obligaton as well as voluntary expressions of faith should be protected under the Quebec (and the Canadian) Charrer. It is the religious or spiritual essence of an action, not any mandatory or perceived-asmandatory nature of its observance, that attracts protection. 
A third term prescribed by the Supreme Court relates to the meaning of religion itself. According to Syndicat Northcrest v. Amselem, the "religion" that Moïse Amselem and the other Orthodox Jewish residents were endeavouring to protect has as its "essence" the selfdefinition and spiritual fulfillment of the individual, and the need for individuals to foster a connection with the divine. Religion is not primarily concerned with the communal recognition of common obligations and beliefs, therefore, nor the "sense of direction or growth that is constituted as the individual and his community work out the implications of their law,"34 but with the spiritual faith of each individual, and the manner in which it allows him or her to be fulfilled. Correspondingly, the essence of religious freedom lies in its function of promoting "personal autonomy and choice, elements which undergird the right." 35 In this sense, the freedom of religion described in Amsclem must almost be understood as an instrumental right, a social "good" which reflects and protects the even more crucial "hypergoods" of Canadian society."

Finally, the Amselem decision requires claimants of religious freedom to accept a vision of society in which autonomy is virtually synonymous with individuality, and in which "[t]he only freedom which deserves the name, is that of pursuing our own good in our own way." "37 The Court's constant emphasis on the "profoundly personal" nature of religious beliefs, and the right of every Canadian to work out his religious obligations on his own, could be seen to promote a social vision in which humanity is defined in the terms of John Stuart Mill:

\begin{abstract}
A person whose desires and impulses are his own - are the expression of his own nature, as it has been developed and modified by his own culture - is said to have character. One whose desires and impulses are not his own, has no character, no more than a steam-engine has character. ${ }^{38}$
\end{abstract}

The Court's statement that "religious beliefs, by their very nature, are fluid and rarely static" reinforces this vision, drawing attention to the social contract theory's generally more veiled assumption that "the human individual is sovereign, rather than God."40 What Amselem seems to prescribe, in sum, is a world where it is better to be "inner-directed" than "outer-directed," and more human to follow our own impulses than to accept communal understandings about the nature of the world and our role within it.

4 Robert M. Cover. "Foreword: Nomos and Narrative" (1983-84 P1. I) 97 I Iarv. L. Rev. 4 at 13 [Cover. "Foreword"].

is Amselem, supra nole I at para. 42.

u. McLachlin, supra note 29 at 33.

"John S. Mill, On Liberty and Considerations on Representative Government (Oxford: Blackwell, 1946) at 11 , cited in Amselem, supra note $I$ at para. 61 ("we live in a society of individuals in which we must always take the rights of others into account. In the words of John Stuart Mill: The only freedom that deserves the name, is that of pursuing our own good in our own way. so long as we do not attempl to deprive others of theirs, or impede their efforts to obtain it") John Stuart Mill, On Libern. (1859) reprinted in John Gray. ed . On J.sberty and Other Essays (Oxford: Oxford University Press, 1991) cited in Jeff Spinner-Halev. Surviving Diversity: Religion and Democratic Citizenship (Baltimore: John Hopkins University Press, 2000) at 29-30.

"Amselem, supra note I at para. 53 [emphasis added]

"David Novak, "Religious Human Rights in Judaic Texts" in Micheal J. Broyde \& John Witte. eds. Human Rights in Judaism: Cultural. Religious and Polutical Perspectives (New Jersey: Jason Aronsun Inc.. 1998) 1 at 7.

$1 \quad$ Spinner-Halev, supra note 38 at 29. 
On one level, the terms set out by the Supreme Court in Syndicat Northcrest v. Amselem are simply further confirmation of how even rights claims of separateness can be fit within the unifying enclosure of the state. However, the intuitive question raised by the decision would the Orthodox Jewish residents have accepted these terms if they were presented as a condition of the law's recognition of their claim? - highlights the fact that the "unifying" function of rights claims only exists because of the dominance of the state's voice. The recognition of this coercive aspect of rights adjudication ${ }^{42}$ poses a challenge to Minow's Russian nesting dolls model, pushing us to question the appropriateness of an image whose serenity obscures the nature of the process by which a religious group's deepest beliefs and greatest aspirations come to "fit" within the normative framework of the dominant state, and whose stability belies the way that constitutional decisions continue to "create" after their release, producing reactions that may threaten the precarious "unity" of the state and its subjects.

Indeed, the more stringently the Russian nesting dolls model is applied to Syndicat Northcrest $v$. Amselem, the more it seems to present a very incomplete picture of how the decision came to be, how the Supreme Court gave voice to the claims of the Orthodox Jewish residents, or the meaning the decision may take on with time. The model does not convey, for example, that the Jewish residents were left with few good options other than a rights claim once the syndicate had applied for an injunction, or how this might colour their apparent "willingness" to use, and then accept, the language of rights. It does not communicate the fact that none of the parties before the Supreme Court presented any argument on what religion itself "means." ${ }^{* 3}$ And it does not address the very real possibility that the type of "religious freedom" described by the Supreme Court in Amselem was not the religious freedom that Molse Amselem and the other Orthodox Jewish residents were seeking at all. All of these factors challenge our assumptions about the "unifying nature" of rights discourse, and raise the question of what might happen if religious communities in Canada find that they can no longer accept the type of religious "space" being carved out for them by the state.

\section{The Duelling NarRatives of RELigious FreEdom}

In addressing the difficult questions raised by the Amselem decision, it seems instructive to consider the interpretations and narratives that religious communities in Canada might themselves attach to the "freedom of religion" guaranteed by our Charters, and the degree to which those interpretations and narratives might differ from those made law by the majority of the Supreme Court. This type of inquiry is crucial, according to Robert Cover, because we inhabit a normative universe (or nomos) in which law and narrative are "inseparably related." ${ }^{24}$ The state may prescribe laws within this nomos; however, it is the

12 Minow, supra note 23 at 355.

" Dr. Janet Epp Buckingham, "Freedom of Religion in Canada and the Changing Judicial Landscape" (Lecture presented at the 2004 Annual Church and Charity Seminar, Toronto, Ont., November 2004) [unpublished].

1. Cover, "Foreword," supra note 34 at 5 :

Every prescription is insistent in its demand to be located in discourse - to be supplied with history and destiny, beginning and end, explanation and purpose. And every narrative is insistent in its demand for its prescriptive point, its moral. History and literature cannot escape their 
narratives and $m y t h o s$ that become attached to the state's laws that will determine paradigms of behaviour and "give rise to effective or ineffective social control."45 Both "official" and "non-official" understandings of state laws, in other words, will affect the meaning and significance of the laws themselves. ${ }^{46}$

Cover claims that legal meaning is typically created in "essentially cultural medi[a],"47 which are characterized by "(1) a common body of precept and narrative, (2) a common and personal way of being educated into this corpus, and (3) a sense of direction or growth that is constituted as the individual and his community work out the implications of their law."43 The state is not well suited to this process of "jurisgenesis"; its predominant function is to ensure the coexistence of different normative communities by exercising rigid social control over the ever-multiplying normative worlds that threaten to dominate and consume each other. ${ }^{49}$ The conclusion that must be drawn from this state of affairs, according to Cover, is that "there is a radical dichotomy between the social organization of law as power and the organization of law as meaning": ${ }^{30}$

\begin{abstract}
The precepts we call law are marked of by social control over their provenance, their mode of anticulation. and their effects. But the narratives that create and reveal the patterns of commitment, resistance, and understanding - patterns that constitute the dynamic between precept and material universe - are radically uncontrolled.... Such is the radical message of the first amendment: an interdependent system of obligation may be enforced, but the very patterns of meaning that give rise 10 effective or ineffective social control are to be left to the domain of Babel. ${ }^{\text {s! }}$
\end{abstract}

How does this dichotomy between the law's "power" and its "meaning" affect our understanding of constitutional decision making? First of all, unlike many sacred religious texts, our constitutional texts do not include both precept and narrative. As a result, many "communities establish their own meanings for constitutional principles"s2 in order to preserve the authority of their own nomos. While judges offer one set of interpretations of constitutional texts, these interpretations are not inherently superior (as a source of meaning) to those of any other community or group..$^{33}$ Second, Cover maintains that the primary

location in a normative universe, nor can prescription. even when embodied in a legal text, escape its origin and its end in experience, in the narratives that are the trajectories plotted upon material reality by our imagination.

Jbid. at 17.

Cover gives as an example the belief of many Americans that the Supreme Court's decision in Roe $v$. Wade licensed the killing of innocent human beings. For these citizens, he suggests, "the principle that 'no person shall be deprived of life without due process of law' has assumed an ironic cast" (ibid. at 7). In Canada, one might tell a similar story about the Preamble to the Canadian Charter of Rights and Freedoms. Part I of the Constitution Act. 1982, being Schedule B to the Canada Act 1982 (U.K.). 1982. c. C-11 [Charter] whose pronouncement that "Canada is founded upon principles that recognize the supremacy of God" has been described as a "dead letter" in Canadian law: see $R$. v. Sharpe (1999). 175 D.L.R. (4th) 1, 1999 BCCA 416, Southin J.A. at para. 79.

Cover, "Foreword," supra note 34 at 11.

Jbid. at 12-13.

sbid.

Ibid. at 18.

lbid. at 17 .

Ibid. at 25.

Ibid. 
function of the courts is not to create law at all, but "to suppress law, to choose between two or more laws, to impose upon laws a hierarchy." 34 This recognition of the court's "jurispathic" role, according to Cover, is consistent with the acknowledgement that different communities offer competing responses to normative problems, but that within the context of each group's normative universe, the legal meaning it offers is necessarily the right response. ${ }^{\text {ss }}$ While the "jurispathic" function of the courts may be necessary to preserve the peace necessary "for the creation of legal meaning in autonomous interpretive communities," 36 it is important to recognize that "imposition of the state's norms does violence to communities ... [and it] is not to be preferred a priori." ${ }^{57}$ Finally, Cover argues that the state's ability to impose legal interpretations on communities does not assure their meaning or their validity. A constitutional decision will only take on legal meaning once a community commits to an understanding of what it stands for, and acts according to that commitment. $^{\text {ss }}$

Cover's "Nomos and Narrative" encompasses a number of fundamental claims about the legitimacy of judicial decision making and the nature of law itself. However, two claims seem to be particularly central to the Amselem decision, and the way in which the Supreme Court of Canada may be distancing itself from the views and experiences of Canada's religious communities. The first is that every religious community attaches its own narratives and interpretations to freedom of religion, which are as important to the organization of law as meaning in Canada as the interpretations put forth by the Supreme Court. The second, even more crucial, claim is that the legal meaning that will ultimately attach to the Supreme Court's pronouncements on religious freedom will depend on the nature of the commitment that those pronouncements generate from religious communities themselves. In thinking about these two claims, it seems useful to consider some of the other stories that could be told about the meaning of religion, and about the character of the fundamental "freedom of religion" that entitles Orthodox Jews to dwell in succahs during the religious festival of Succot. There are many such stories; this comment will briefly consider four.

\section{A. A StORY OF The HiERARChy OF Rigits}

In 1965, the Second Vatican Council precipitated the Catholic Church's entry into the "human rights revolution" by releasing its own narrative on the source and nature of religious freedom. The Council's Declaration of Religious Freedom, or Dignitatis Humanae, contains the following statement:

lbid. at 40.

See Cover, "Foreword," ibid. at 42

To state, as I lave done, that the problem is one of too much law is to acknowledge the nomic integrity of each of the communities that have generated principles and precepts. It is to posit that each "community of interpretation" that has achicved "law" has its own nomos - narratives, experiences, and visions to which the norm articulated is the right response. And it is to recognize that different interpretive communities will almost certainly exist and will generate distinctive responses to any normative problem of substantial complexity.

Ibid. at 44.

" Martha Minow, "Introduction: Robert Cover and Law. Judging, and Violence" in Martha Minow. Michael Ryan \& Austin Sarat, eds., Narrative, Violence, and the Law: The Essays of Robert Cover (Ann Arbor: University of Michigan Press. 1992) I at 2.

s* Covet. "Foreword," supra note 34 at 45. 
The Vatican Council ... declares that the right to religious freedom has its foundation in the very dignity of the human person as this dignity is known through the revealed word of God and by reason itself. This right of the human person to religious freedom is to be recognized in the constitutional law whereby society is governed and thus it is to become $\mathfrak{a}$ civil rightt... Therefore the right to religious freedom has its foundation not in the subjective disposition of the person, but in his very nature. In consequence, the right to this immunity continues to exist even in those who do not live up to their obligation of secking the truth and adhering to it and the exercise of this right is not to be impeded, provided that just public order be observed. 59

This authoritative narrative has generated an important element of the Catholic nomos as it relates to freedom of religion. As Jean Bethke Elshtain explains, Roman Catholic teaching acknowledges a hierarchy of rights, which is "topped" by the right to religious freedom. The meaning that is taken from Dignilatis Humanae, in other words, is that "the right to religious freedom has priority because this right speaks most pointedly to the Urgrund of human rights; namely, the ordering of our very selves, in our created nature, to the truth, and 'especially religious truth." ${ }^{60}$ Within the nomos which the Dignitatis narrative creates, the "correct" resolution of Syndicat Northcrest v. Amselem seems fairly clear. Moise Amselem's freedom of religion, a freedom rooted in his very nature, is a priori more valuable than the rights of property and personal security being claimed by the syndicate. Therefore, it is unnecessary to consider how its exercise might "cause harm to"6l the syndicate's rights or interfere with their exercise. So long as the construction of individual succahs on private balconies does not "threaten public order," it is an activity that must not be impeded by the state.

Interestingly, echoes of the Catholic narrative of the hierarchy of rights can be found in the historical narrative of religious freedom recounted by Canadian law. Several judges in the pre-Bill of Rights period acknowledged the "fundamental" character of religious freedom, and its roots in the very nature of man. The most celebrated of these statements was made by Rand J., who articulated his vision of religious freedom as a "necessary attribute" of human beings in Saumur v. City of Quebec:

Strictly speaking, civil rights arise from positive law; but freedon of speech, religion and the inviolability of the person, are original freedoms which are at once the necessary attributes and modes of self-expression of human beings and the primary conditions of their community life within a legal order. It is in the circumscription of these liberties by the creation of civil rights in persons who may be injured by their exercisc, and by the sanctions of public law, that the positive lau operates."

5. His Holiness Pope Paul VI. "Declaration on Religious Freedom: On the Right of the Person and of Communities to Social and Civil lireedom in Matters Religious" (7 December 1965), online: The / loly Sec <www.vatican.va/archive/hist_councils/ii_vatican_council/documents/vat-ii_decl_196512017. dignitatis-humanae_en.html> at art. 2 [Digniratis Humernae] [footnolt ontitted]. Jean Bethke Elshtain, "Persons. Politics and a Catholic Understanding of Human Rights" in Farrow. supra note 24,69 at 77 . Amselem. supra note 1 at para. 62

Saumur v. Cin of Quebec. |1953) 2 S.C.R. 299 at 329 [Saumur] See also Chabor v. Sch. (om rn of Lamorandiere (1957), 12 D.L.R. (2d) 796 (Que. C.A.) ("ll is well to remember that the [religious| rights of which we have been speaking. find their source in natural law... On this point there can be no douht for if these rights find their source in positive law they can be taken away. But if, as they do. they find their existence in the very nature of man. then they cannot be taken away and they must prevant should they conflict with the provisions of positive law") at 807 
The narrative of the hierarchy of rights has waned, however, in recent cases on the meaning of religious freedom. In the context of the Canadian Charter, this decline may be attributable to the great importance that has been attached to equality rights, the status of all Charter rights as part of the "supreme law of Canada," conflicting Charter rights be balanced in a way "that fully respects the importance of both sets of rights." Nevertheless, the suggestion in $\mathrm{Amselem}$ that religious freedom and private property rights are "correspondingly important rights" in the context of the Quebec Charter pushes this vision of the parity of rights still further, raising the question of whether Rand J.'s narrative continues to have a place in Canadian law.

\section{B. A Story OF Religious Obligation AND ObedienCE}

If we turn to a second passage from Dignitatis Humanae, we find yet another narrative which gives meaning to the nature and purpose of religious freedom:

It is in accordance with their dignity as persons - that is, beings endowed with reason and free will and therefore privileged to bear personal responsibility - that all men should be at once impelled by nature and also bound by a moral obligation to seck the truth, especially religious truth. They are also bound to adhere to the truth, once it is known, and to order their whole lives in accord with the demands of truth. However, men cannot discharge these obligations in a manner in keeping with their own nature unless they enjoy immunity from external coercion as well as psychological freedom. ${ }^{65}$

According to this Catholic teaching, the purpose of religious freedom is not to allow each individual the opportunity to pursue his or her own "self-definition and spiritual fulfillment," 66 as $A$ mselem claims, but to enable each individual to fulfill his responsibility to seek and adhere to "the truth." In this sense, the Catholic narrative of moral obligation is not unlike the Sinaitic myth of heteronomy, which gives rise to a system of obligations that Jewish persons are both commanded and privileged to fulfill. ${ }^{67}$

These narratives of obligation and obedience, while not offering as obvious a solution to the Amselem conflict as the narrative of the hierarchy of rights, nonetheless evoke an interpretation of religious freedom which may have particular resonance for historically persecuted religious groups in Canada. Under this interpretation, freedom of religion is a privilege, a gift from God that heightens the moral obligation of His subjects to "order their whole lives in accord with the demands of the truth." ${ }^{68}$ The narratives of obligation and obedience make sense of an understanding of religious freedom to which Moise Amselem may well have been committed - that to the extent he was immune from external and psychological coercion, he was obliged to "bring back branches from olive and wild olive trees ... to make booths - as it is written." ${ }^{169}$ They help us to grasp the possibility that for the

Charter, supra note 46, s. $52(1)$.

Dageniais v. Canadian Broadcasting Corp., [1994] 3 S.C.R. 835 at 877.

Dignilatis Humanae, supra note 59 at an. 2.

Amselem, supra note I at para. 39.

See Robert Cover, "Obligation: A Jewish Jurisprudence of the Social Order" in Minow, Ryan \& Sarat, supra note 57,239 at 245.

Dignatatis Humanae, supra note 59 at art.2.

Neh. 8:2-3, 13-15. 
Orthodox Jewish residents of Le Sanctuaire, the act of building succahs may have been compelled by the meaning of religious freedom itself.

\section{A STORY OF THE FreEdom to LIVE A LIFE OF OBEDIENCE}

There is in fact another story of "obedience" that is told about religious freedom, one whose source lies not in any religious community or divine imperative, but in the "cultural medium" of liberalism itself. This tale of the freedom to live a life of obedience is told by Jeff Spinner-Halev, a liberal theorist who emphasizes that most religious conservatives choose a life that values obedience over individuality:

People do not become Hasidic Jews or Protestant fundamentalists to express their inner nature in their own way, nor do they want to interpret their experience in their own way. They don't lead a life of reason, but of faith. (Some lead a life of reason and faith). To say they lack individuality, or that they do not live by reason, however, is not to say that they haven't made or are incapable of making a choice... Religious conservatives choose their way of life, a choice that many of them are reminded of almost every day in liberal societies. ${ }^{\text {70 }}$

Unlike many liberal theorists, Spinner-Halev rejects the view that liberalism requires every cultural community to provide an adequate range of options for its members, or to encourage its members to make independent choices. Rather, the liberal state should respect an individual's choice to live a life of obedience, recognizing that "[l]iving the restrictive life takes a depth of commitment and character that many people lack." "1 According to this narrative, we might say freedom of religion "means" that an individual may make one fundamental choice to obey a set of religious beliefs, rather than dozens of choices to believe particular things at particular times, without reducing his personhood to that of a "steam engine." Because freedom of religion protects Moise Amselem's choice to lead his life as an Orthodox Jew, in other words, it must also protect the religious practices that flow from that choice, irrespective of whether Mr. Amselem himself believes that every one of those practices is necessary in order to connect with the divine.

As with the narrative of the hierarchy of rights, threads of the narrative of the freedom to obey run throughout Canadian law. In fact, Cartwright C.J.C. related a very similar story in 1970 , as he considered whether a religious minority group could require its members to obey tenets that were inconsistent with the values of liberal society:

There is no doubt that the Hutterian way of life is not that of the vast majority of Canadians, but it makes manifest a form of religious philosoplyy to which any Canadian can subscribe and it appears to me that if any individual either through birth within the community or by choice wishes to subseribe to such a rigid form of life and to subject himself to the harsh disciplines of the Hutterian Church, he is free to do so. ${ }^{72}$

The narrative of the freedom to obey might also be said to have a place in Syndicat Northcrest $v$. Amselem, to the extent that the majority recognized that freedom of religion

Hofer v. Interlake Colony of Hutterian Brethren, [1970] S.C.R. 958 at 974-75. 
protects "both obligatory as well as voluntary expressions of faith."" However, it fits somewhat uneasily with the tenor of the Amselem decision, and its constant emphasis on selffulfillment, personal autonomy and choice. If the narrative of the freedom to obey was not extinguished in Amselem, it was deprived of some of its symbolic support. For if "the only freedom which deserves the name, is that of pursuing our own good in our own way," it it is hard to escape the conclusion that pursuing God's good in God's way is a lesser choice.

\title{
D. A STORY OF RELigious AutIIORITY AND COMMUNITY BELIfF
}

A final narrative, this one about religious beliefs and practices and the way they are situated within communities, finds voice in this Talmudic story about the interpretation of religious law:

\begin{abstract}
On a certain occasion Rabbi Eliezer used all possible arguments to substantiate his opinion, but the Rabbis did not accept it. He said, "If I am right. let this carob tree prove it!" Thereupon the carob tree was torn a hundred cubits out of its place. They said, "Irom a carob tree no proof can be brought."... Then Rabbi Lliezer said: "If I am right, let the Heavens prove it." Then a Heavenly voice said, "what have you against Rabbi Eliezer? The halakhah is always with him. " Then Rabbi Joshua got up and said, "it is nol in Ileaven." "What did he mean by this?" Rabbi Jeremiah said. "the law was given to us from Sinai. We pay no attention to a Heavenly voice. For already from Sinai the law said "By a majority you are to decide." Rabbi Nathan met Elijah the Prophet and asked him what God did in that hour. Elijah replied: "He laughed, and said, my children have conquered Me.,"
\end{abstract}

This story of Rabbi Eliezer and his dissenting views establishes an important aspect of the Jewish nomos as it relates to the scope of protected religious practices and beliefs. As Samuel Hoenig explains, it stresses that religious law is to be administered by the religious community's designated interpreters, whose interpretations are binding on God himself. ${ }^{76}$ It also teaches that in doubtful cases, it is not the "wisest" voice (or even the voice of God), but the view of the majority that will prevail. The Amselem litigation presents an interesting scenario for this story of religious authority and community belief, as both parties called rabbis to present conflicting "expert evidence" on whether the Law relating to the festival of Succot requires the erection of individual succahs. However, if we imagine that within the nomos created by this narrative, religious freedom only protects the practices recognized by the community's authorized interpreters, the "correct" resolution of Syndicat Northcrest $v$. Amselem would seem to depend on the majority view among Orthodox Jewish rabbis as to whether Moïse Amselem and the other residents required "their own succah, each on his own balcony" ${ }^{177}$ to fulfill the biblical command.

Narratives of religious authority and community belief have always posed a challenge to the courts, which harbour legitimate concerns about their threat to individual autonomy and the way they can entangle courts in matters of religious doctrine. Nevertheless, even the tale

\footnotetext{
". Amselem, supra nole I at para. 47.

7. Mill, supra note 37, cited in Amselem, supra note I at para. 6I.

"Baba Merzia 59b, cited in Samuel N. Hoenig. The Essence of Talmudic Law and Though (New Jersey Jason Aronson (nc., 1993) at 73.

\%. Hoenig, ibid. at 74.

3 Amselem, supra note 1 at para. 14
} 
of Rabbi Eliezer has a limited place in Canadian law, finding echoes in passages such as Rand J.'s description of freedom of religion as one of the "primary conditions of their community life within a legal order,"78 and Bastarache J.'s statement that freedom of religion "has genuine social significance and involves a relationship with others." 79 However, the narrative clashes badly with the nomos established by the majority in Syndicat Northcrest $v$. Amselem, in which it is of no consequence whether a claimant's religious beliefs are obligatory tenets of a particular faith, or even whether they are "recognized as valid by other members of the same religion." dissent's view of religions as "necessarily collective endeavours," 81 and its holding that claimants must establish "[a] nexus between personal beliefs and [their] religion's precepts" in order to establish a religious right.

\section{What Happens When the Narkatives Get Too Far Apart?}

As the author's "duelling narratives" have endeavoured to illustrate, there are many different stories that can be told about religious freedom, stories which diverge to varying extents from the story told by the majority of the Supreme Court of Canada in Syndicat Northcrest $v$. Amselem. These diverse narratives are obviously important to the communities that have created them, and that continue to rely on them in interpreting the world. The question which remains, however, is whether their existence, or the fact of their recognition or non-recognition by the Supreme Court, is significant for Canadian constitutional law.

The answer to this question, it seems, lies in Cover's observations :iout the dichotomy between law as power and law as meaning, and the fact that it is these "radically uncontrolled" narratives of religious freedom that create patterns of commitment or resistance to judicial rulings, and ultimately determine the effectiveness of the law's social control. As Cover clarifies, a judicial interpretation alone cannot create legal meaning, which requires "subjective commitment to an objectified understanding of a demand." 83 The meanings that are ultimately attached to the Supreme Court's constitutional decisions, therefore, will depend on how the decisions are understood by the communities they affect, and the nature of the commitments and response which those understandings generate. Ultimately, it is those legal meanings that will shape the effectiveness of the law's social control over its subjects. Put more bluntly, "a legal interpretation cannot be valid if no one is prepared to live by it." Any community that is confronted with a judicial interpretation that conflicts with its normative world must decide if it is "prepared to live by it," and then respond by elaborating a "hermeneutic of resistance or of withdrawal." 8 s

7* Saumur, supra note 62 at 329.

Amselem. supra nole I at para. 137.

ibid. at para. 43.

"I Timothy Macklem. "Faith as a Sccular Valte" (2000) 45 McGill L.J I. ciled in Amselem, supra note 1 at para. 137.

n: Amselem, ibid. at para. 135.

"I Cover, "Foreword," supra note 34 at 45.

nt Ibid. at 44.

ns $\quad$ bid. at 53 . 
What do these observations suggest about Syndicat Northcrest v. Amselem, and the meaning it might come to take on? Having considered the interpretation of religious freedom made (state) law by the Supreme Court and the extent to which it suppresses or "kills" their own law, Orthodox Jews, Sikhs and other religious groups will have to decide how they are going to respond. Some may withdraw, changing the rules and practices within their communities that conflict directly with the Court's individualistic vision. Other groups may decide they are prepared to live by the decision even if that means "freedom of religion" comes to assume a somewhat "ironic cast."

However, given the strength of many religious communities' commitment to their normative worlds, and the extent to which some of these nomoi clash with the world prescribed by Syndicat Northcrest $v$. Amselem, it seems prudent to consider the possibility that some groups will respond to the $A m s e l e m$ decision by starting to resist the coercive force of the state. This resistance may not amount to the type of "open defiance and disobedience of the law"86 that characterized the acts of the Doukhobors in British Columbia after the courts denied the Doukhobor community the right to raise its children in accordance with its religious beliefs. ${ }^{87}$ It may be, however, that the next time Orthodox Jews (or Sikhs or Protestants, for that matter) face a battle to protect their religious beliefs and practices, they will look to do so in a way that is less threatening to their community's autonomy and the integrity of its beliefs. If the "space" being carved out by the courts for the manifestation of competing ultimate commitments is unacceptable to religious groups, in other words, they will seek to avoid the courts and their "unifying discourse" at all costs. And this should be a matter of great concem for a legal institution that seeks to continue to assert its dominance over the competing worlds of normative meaning that exist in Canadian life.

\section{CONCLUSION}

The jurispathic acts of judges may be necessary, as Cover states, to permit "a life of law rather than violence." ${ }^{88}$ If the state were to use its coercive power to impose on society an understanding of freedom of religion that obliges people to "adhere to the truth," other core values of our constitutional democracy, such as autonomy and liberty, might suffer a cruel fate. If the courts were to accept that the view of the majority must always prevail within religious communities, they could not adequately safeguard equality rights or the security of the person. The Supreme Court of Canada cannot possibly accept all of the normative worlds encompassed by Canada's religious communities, either as a matter of principle or practice. However, the courts may be able to respond to these competing nomoi in ways that will encourage sub-communities to stay within the "Russian nesting doll" of the state.

Elshtain notes that "at present, to trigger open defiance and disobedience of law from the side of the vast majority of religious believers, the provocation must be quite substantial. Dissent and disagreement - the stuff of democratic politics, after all - are far more common": Jean Bethke Elshtlain, "A Response to Chief Justice McLachlin" in Farrow, supra note 24,35 at 37, n. 2. However, the Doukhobors' use of arson and public nudity to protest government intrusion in their lives presents a powerful reminder that simple dissent and disagreement have not always characterized religious resistance movements in Canada. 
How can the courts do this? While this issue will require more substantial research and thought, two initial suggestions may be made. First, in interpreting open-ended and valueladen terms such as "freedom of religion," it may be helpful for judges to acknowledge that theirs is but one of many competing understandings of what the law "means." As Minow points out, judicial rulings that are framed in the language of rights tend to veil the competition between state norms and the norms of other communities "behind a guise of neutrality and universality. ${ }^{89}$ The unfortunate message that emerges from this guise is that the competing responses of religious communities are "wrong," rather than simply incompatible with the nomos of the state. By explicitly recognizing the alternative responses which different communities might offer to resolve the issue before the court, and by explaining why the court's chosen interpretation must prevail over those responses within the nomos of Canada's constitutional democracy, the court may be able to combat the view that its claim over legal meaning arises solely from "the state's imperfect monopoly over the domain of violence, ${ }^{, 90}$ and achieve a greater measure of respect from those whose competing law it has suppressed.

Second, the courts need to continually consider if and how the competing narratives of religious freedom may be able to find a place within the dominant structures of the law. As this comment has attempted to show, there are precedents for this task, decisions in which Canadian judges have succeeded in incorporating important aspects of the nomoi of religious communities into their reasoning and conclusions. This is admittedly a challenging undertaking, and one that will increase in difficulty the more that the values and understandings of the religious community before the court depart from those of the state. However, the risk of not accepting this challenge is that religious communities will increasingly start to reject the space carved out for them within the larger enclosure of the state, leaving religious persons such as Moise Amselem content to carry out their religious obligations, with or without the courts' blessing. Ass it is written. 